\title{
Effects of dietary fibre and exercise on mid-morning diabetic control-a controlled trial
}

\author{
J H BAUMER, J A DRAKEFORD, J WADSWORTH, AND D C L SAVAGE \\ Department of Child Health, Royal Hospital for Sick Children, Bristol
}

SUMmARY Twenty-one insulin-dependent diabetic children completed a trial of 4 different breakfasts, given in random order. Three diets differed in fibre content. The fourth diet contained soya beans as part $(38 \%)$ of the dietary fibre source. Children collected capillary blood samples on to filter paper strips which were analysed for blood glucose content. Each morning the children were asked to exercise vigorously for an hour and to rest for an hour, resulting in comparable rest and exercise periods for each child. Mean initial blood glucose levels on the 4 diets were not significantly different. The low-fibre diet resulted in the highest blood glucose concentrations after break kfast. Blood glucose levels on the high-fibre diet did not differ from those on the medium-fibre diet. The bean diet produced the lowest mean blood glucose level and the smallest reduction in blood glucose level in the hour before lunch. All the children found the bean diet unacceptable but liked the high-and medium-fibre diets, which were as popular as the low-fibre diet. The level of prescribed exercise had no effect on the level of blood glucose. It appears that the potentially major benefits from beans are limited by their unpalatability. The more acceptable cereal fibre produces a smaller but important benefit on morning hyperglycaemia after breakfast.

Mid-morning hyperglycaemia is a major problem in the diabetic child, even if control is fairly good during the rest of the day. Diets rich in natural fibre have been shown to reduce post-prandial hyperglycaemia and improve diabetic control in insulin ${ }^{1-4}$ and noninsulin-dependent ${ }^{2} 5$ adults. Indeed, the British Diabetic Association now recommends a high-fibre diet for all diabetics. ${ }^{6}$ Beans as the source of dietary fibre result in an exceptionally low blood glucose response. ${ }^{78}$

Experiments in vitro ${ }^{9}$ confirm the slow release of glucose from beans during the process of digestion, but this is probably not the only mechanism, as improved glucose tolerance continues for up to 4 hours. ${ }^{10}$ Unfortunately, legumes are not acceptable in large quantities partly because they involve a major departure from the normal British diet, and partly because of unpleasant side effects, including increased stool bulk and flatus production.

In the only study ${ }^{11}$ in diabetic children on the effects of dietary fibre, no attempt was made to differentiate the effects of beans from other sources of dietary fibre. Without such information, there is no rational basis for advising diabetic children and their families to increase the dietary fibre content, unless this includes regular beans. The aim of the present study was to compare the benefits of beans and other dietary fibre sources in reducing morning hyperglycaemia in children. It was also designed to assess the effects of short periods of exercise on diabetic control.

\section{Method}

Twenty-eight insulin-dependent diabetic children were asked to provide capillary blood samples on 8 mornings, while eating 4 different breakfasts and mid-morning snacks. Twenty-four of the children provided suitable blood spots, and 21 completed the study. All the children were thought to be reasonably well controlled, were aged between 7.1 and $16 \frac{1}{2}$ years (median 12 years 10 months), and had been diagnosed from 7 months to $10 \frac{1}{2}$ years (median 3 years). Insulin dosage varied between 0.4 and 1.5 (median $0 \cdot 9)$ units per kilogram a day. Insulin (a combination of a short- and long-acting insulin) was injected 30-45 minutes before breakfast; neither the insulin dosage nor the timing of injections was altered during the study. Three of the $\mathbf{4}$ diets differed only in the fibre content (Table). The fourth diet was similar to the high-fibre diet, except that $38 \%$ of the fibre source was from soya beans.* All 4 diets contained similar amounts of carbohydrate, fat, and

*Canned soya beans supplied by Granose Food Company, Watford, Herts. 
Table Food constituents of the 4 diets

\begin{tabular}{|c|c|c|c|c|c|c|}
\hline Diet & Food & Calories & Fibre (g) & Carbohydrate & Fat & $\operatorname{Protein}(\mathrm{g})$ \\
\hline \multirow[t]{2}{*}{ Breakfast } & $\begin{array}{l}\text { re per } 100 \text { calories) } \\
15 \mathrm{~g} \mathrm{Weetabix} \\
15 \mathrm{~g} \mathrm{bran} \\
200 \mathrm{ml} \text { milk } \\
40 \mathrm{~g} \text { wholemeal bread }\end{array}$ & $\begin{array}{r}51 \\
11 \\
130 \\
86\end{array}$ & $\begin{array}{l}1.9 \\
\frac{2 \cdot 2}{3 \cdot 4}\end{array}$ & $\begin{array}{r}10 \cdot 5 \\
1 \cdot 4 \\
9 \cdot 4 \\
16 \cdot 7\end{array}$ & $\begin{array}{l}0 \cdot 5 \\
0 \cdot 3 \\
7 \cdot 6 \\
1 \cdot 1\end{array}$ & $\begin{array}{l}1 \cdot 7 \\
0.7 \\
6 \cdot 6 \\
3 \cdot 5\end{array}$ \\
\hline & Totals & 278 & $7 \cdot 5$ & $38 \cdot 0$ & $9 \cdot 5$ & $12 \cdot 5$ \\
\hline \multirow[t]{2}{*}{ Snack } & $\begin{array}{l}20 \mathrm{~g} \text { Ryvita } \\
10 \mathrm{~g} \text { peanut butter } \\
90 \mathrm{~g} \text { apple }\end{array}$ & $\begin{array}{l}64 \\
62 \\
40\end{array}$ & $\begin{array}{l}2 \cdot 3 \\
0 \cdot 8 \\
1 \cdot 8\end{array}$ & $\begin{array}{r}14 \cdot 1 \\
1 \cdot 3 \\
10 \cdot 7\end{array}$ & $\begin{array}{l}0.4 \\
5 \cdot 4 \\
-\end{array}$ & $\begin{array}{l}1 \cdot 9 \\
2 \cdot 3 \\
0 \cdot 3\end{array}$ \\
\hline & Totals & 166 & 4.9 & $26 \cdot 1$ & $5 \cdot 8$ & $4 \cdot 5$ \\
\hline \multicolumn{7}{|c|}{ Medium fibre ( $0.8 \mathrm{~g}$ of fibre per 100 calories) } \\
\hline \multirow[t]{2}{*}{ Breakfast } & $\begin{array}{l}15 \mathrm{~g} \text { cornflakes } \\
200 \text { ml milk } \\
40 \mathrm{~g} \text { white bread }\end{array}$ & $\begin{array}{r}55 \\
130 \\
93\end{array}$ & $\frac{1 \cdot 7}{1 \cdot 1}$ & $\begin{array}{r}12 \cdot 7 \\
9.4 \\
20 \cdot 0\end{array}$ & $\begin{array}{l}0 \cdot 2 \\
7.6 \\
0 \cdot 7\end{array}$ & $\begin{array}{l}1 \cdot 3 \\
6 \cdot 6 \\
3 \cdot 1\end{array}$ \\
\hline & Totals & 278 & $2 \cdot 8$ & $42 \cdot 1$ & $8 \cdot 5$ & $11 \cdot 0$ \\
\hline \multirow[t]{2}{*}{ Snack } & $\begin{array}{l}20 \mathrm{~g} \text { cream cracker biscuits } \\
10 \mathrm{~g} \text { cheese spread } \\
120 \mathrm{ml} \text { unsweetened orange juice }\end{array}$ & $\begin{array}{l}88 \\
28 \\
40\end{array}$ & $\begin{array}{l}0 \cdot 6 \\
-\end{array}$ & $\begin{array}{r}13 \cdot 7 \\
0 \cdot 1 \\
10 \cdot 2\end{array}$ & $\begin{array}{l}3 \cdot 3 \\
2 \cdot 3 \\
-\end{array}$ & $\begin{array}{l}1.9 \\
1.8 \\
0.5\end{array}$ \\
\hline & Totals & 156 & 0.6 & $24 \cdot 0$ & $5 \cdot 6$ & $4 \cdot 2$ \\
\hline \multicolumn{7}{|c|}{ Low fibre $(0.3 \mathrm{~g}$ of fibre per 100 calories $)$} \\
\hline \multirow[t]{2}{*}{ Breakfast } & $\begin{array}{l}15 \mathrm{~g} \text { Rice Krispies } \\
150 \mathrm{ml} \text { milk }+10 \mathrm{~g} \text { Marvel } \\
30 \mathrm{~g} \text { white bread } \\
5 \mathrm{~g} \text { ordinary jam }\end{array}$ & $\begin{array}{r}56 \\
134 \\
70 \\
13\end{array}$ & $\begin{array}{l}0.7 \\
0.8 \\
-\end{array}$ & $\begin{array}{r}13 \cdot 2 \\
12 \cdot 3 \\
14 \cdot 9 \\
3 \cdot 4\end{array}$ & $\begin{array}{l}0 \cdot 3 \\
5 \cdot 8 \\
0 \cdot 5 \\
-\end{array}$ & $\begin{array}{l}0 \cdot 9 \\
8 \cdot 6 \\
2 \cdot 3 \\
0 \cdot 03\end{array}$ \\
\hline & Totals & 273 & $1 \cdot 5$ & $43 \cdot 8$ & $6 \cdot 6$ & $11 \cdot 8$ \\
\hline Snack & $36 \mathrm{~g}$ (1) Wagon Wheel biscuit & 166 & 一 & $24 \cdot 5$ & 6.9 & 1.5 \\
\hline \multirow[t]{2}{*}{ Breakfast } & $\begin{array}{l}\text { er } 100 \text { calories) } \\
40 \mathrm{~g} \text { wholemeal bread } \\
213 \mathrm{~g} \text { soya beans }\end{array}$ & $\begin{array}{r}87 \\
252\end{array}$ & $\begin{array}{l}3 \cdot 4 \\
2 \cdot 3\end{array}$ & $\begin{array}{l}16 \cdot 7 \\
25 \cdot 6\end{array}$ & $\begin{array}{l}1 \cdot 1 \\
8 \cdot 3\end{array}$ & $\begin{array}{r}3 \cdot 5 \\
20 \cdot 2\end{array}$ \\
\hline & Totals & 339 & $5 \cdot 7$ & $42 \cdot 3$ & $9 \cdot 4$ & $23 \cdot 7$ \\
\hline \multirow[t]{2}{*}{ Snack } & $\begin{array}{l}20 \mathrm{~g} \text { Ryvita } \\
107 \mathrm{~g} \text { soya beans }\end{array}$ & $\begin{array}{r}64 \\
126\end{array}$ & $\begin{array}{l}2 \cdot 3 \\
1 \cdot 2\end{array}$ & $\begin{array}{l}14 \cdot 1 \\
12 \cdot 8\end{array}$ & $\begin{array}{l}0.4 \\
4 \cdot 2\end{array}$ & $\begin{array}{r}1.9 \\
10 \cdot 1\end{array}$ \\
\hline & Totals & 264 & $3 \cdot 5$ & 26.9 & $4 \cdot 6$ & $12 \cdot 0$ \\
\hline
\end{tabular}

calories, and had the same fluid content $(520 \mathrm{ml})$. There was a higher protein content in the bean diet. The 4 diets were given in random order, each one repeated on 2 consecutive mornings. Capillary blood samples were taken by the children themselves using an autolet on to filter paper strips immediately before, and 30, 60, and 120 minutes after both breakfast and the mid-morning snack ( 7 samples in all), and the samples sent to the laboratory for blood glucose analysis, using a modified glucose oxidase method. ${ }^{12}$

Statistical significance was assessed using analysis of variance on the results from the 21 children completing the test. Blood glucose levels at the 7 times during the morning were compared on the 4 diets.
Each day the children were asked to exercise vigorously for an hour and to rest for an hour before the snack and before the last blood glucose estimation, before lunch. These two periods of exercise and rest were alternated each day, resulting in 8 pairs of comparable exercise and rest periods for each child. Differences in blood glucose changes between the exercise and rest periods were estimated for each child. No attempt was made to quantify the amount of exercise taken; the children were asked to exercise vigorously in whatever way they liked. In practice, cycling, running, and walking were the most common forms of exercise, but many children undertook a wide variety of activities.

The study was approved by the District Ethical Committee. 


\section{Results}

There was nosignificant difference in the fasting blood glucose levels before the 4 diets. With the bean diet the mean blood glucose level one hour after breakfast was $5.2 \mathrm{mmol} / 1(93.7 \mathrm{mg} / 100 \mathrm{ml})$ lower than on the low-fibre diet, and $3.4 \mathrm{mmol} / 1(61.3 \mathrm{mg} / 100 \mathrm{ml})$ lower than on the high-fibre diet (Fig. 1). The mean blood glucose level wassubstantially lower $(P<0.001)$ on the bean diet than on all other diets up to half an hour after the snack and remained significantly lower $(\mathrm{P}<0.01)$ for a further half hour. There was no significant difference in the mean blood glucose levels between the high- and medium-fibre diets at any time. The low-fibre diet resulted in higher $(P<0.05)$ mean blood glucose values than the medium-fibre diet from one hour after breakfast to one hour after the snack. The mean blood glucose level 2 hours after the snack fell significantly less $(P<0.05)$ with the beans than with the other snacks (Fig. 2).

There was no significant change in blood glucose level with exercise. The average change after exercise was $-2 \cdot 1 \mathrm{mmol} / 1(-37.8 \mathrm{mg} / 100 \mathrm{ml})$, and after the rest period $-2.2 \mathrm{mmol} / 1(-39.6 \mathrm{mg} / 100 \mathrm{ml})$. The blood glucose level at the time that exercise was taken had no influence on its effects. Estimation of type II errors indicated that there was a $5 \%$ chance of missing a difference of $0.7 \mathrm{mmol} / 1(12.6 \mathrm{mg} / 100$ $\mathrm{m} l)$ in change in blood glucose level owing to exercise.

Twenty of the children were asked which diet they preferred. All except one disliked the bean breakfast and snack. Half the children thought the low-fibre diet the most enjoyable. All except one were already

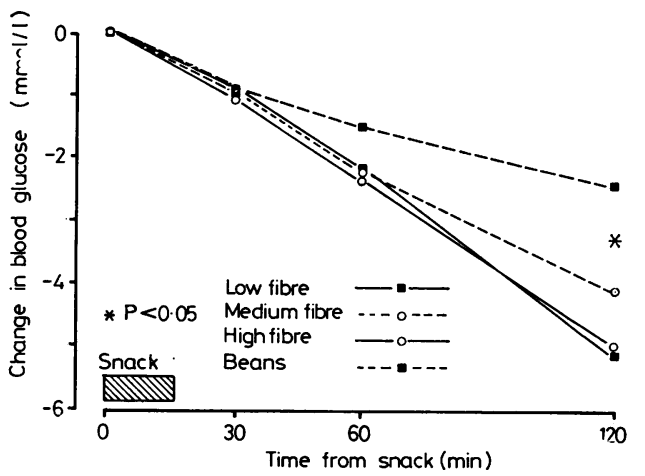

Fig. 2 Mean change in blood glucose concentration after snack.

eating a medium- or high-fibre diet (this was being encouraged in the clinic at the time of the study).

Symptomatic hypoglycaemia was reported by only one child on 2 mornings before lunch, once with the high-fibre diet and once with the beans.

\section{Discussion}

Diabetic control is notoriously difficult to gauge accurately, ${ }^{13}$ although its assessment has been greatly improved by the advent of glycosylated haemoglobin measurement and home blood glucose monitoring. These two methods confirm the poor quality of control in most children with diabetes. ${ }^{14}$ Two recent studies ${ }^{15}{ }^{16}$ show the high blood glucose levels that occur on both once- and twice-daily insulin regimens, especially after breakfast. Postprandial hyperglycaemia may be reduced by

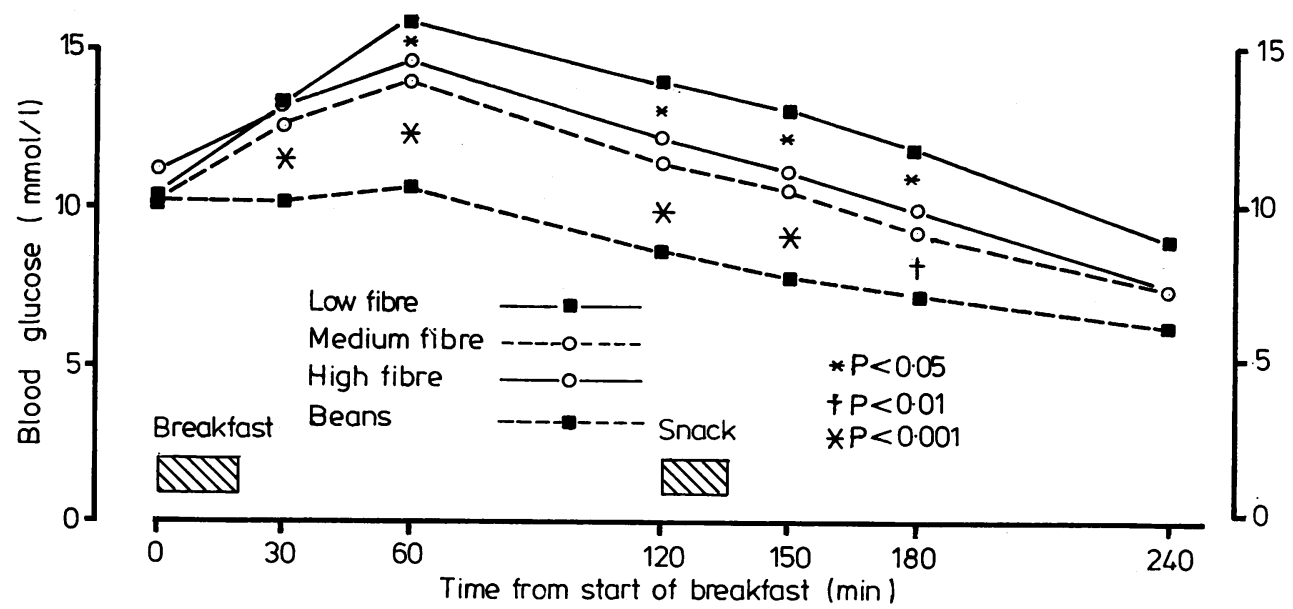

Fig. 1 Mean of blood glucose values in 21 children during test period. 
increasing the time between the morning injection and breakfast, ${ }^{17}$ and further improvement may be obtained through dietary changes-for example, by altering the quality or reducing the load of carbohydrate at breakfast. There is still controversy about the optimum carbohydrate content of diabetic diets, ${ }^{18}$ and wide variations occur in clinical practice. ${ }^{19}$ In our study, carbohydrate contributed between $51 \%$ and $61 \%$ of the calories at breakfast.

We have demonstrated in a short-term study that hyperglycaemia after breakfast can be prevented by using beans as the major source of carbohydrate; longer-term studies in adults ${ }^{4}$ and children ${ }^{11}$ have demonstrated a concomitant reduction in fasting blood glucose. Compared with the other diets, beans also resulted in a smaller decrease in blood glucose between the snack and lunch, suggesting that prolongation of glucose absorption, as shown in vitro by Jenkins et al., ${ }^{9}$ is one cause of the reduced hyperglycaemia. We confined our investigation to blood glucose, but studies in adults $^{34}$ show a lowering of blood cholesterol and triglyceride concentrations.

The children did not like the beans. Four failed to start the study because they could not face eating the beans, and a further 3 children did not complete the study because they found the beans unpleasant. Many of those who ate the beans complained of nausea and some of diarrhoea. A number made it clear that they would not be prepared to eat the beans again. Beneficial effects from popular 'baked beans' (haricot beans in tomato sauce) are prevented by the large quantities of added sugar, ${ }^{7}$ but other types of bean are likely to provide acceptable recipes. In this study beans formed only $35-40 \%$ of the dietary fibre content on the days that they were used but even smaller quantities may help to prevent hyperglycaemia. However, it seems unlikely that many children could be persuaded to eat beans regularly without substantial changes in their families' dietary habits.

The fibre content of the medium-fibre diet corresponds closely to that of the average British diet. ${ }^{20}$ We failed to demonstrate any difference in blood glucose levels between this diet and the one with a high-fibre content. Both diets significantly reduced the hyperglycaemia after breakfast compared with the low-fibre diet. Although most children in the study found the high level of cereal fibre acceptable, there is no evidence in children of benefit from high-fibre diets unless these include beans, either from this study or that of Kinmonth et al. ${ }^{11}$ However, appreciable long-term benefits may be obtained from the avoidance of low-fibre foods.

It is beneficial for diabetic patients to exercise regularly, ${ }^{21}$ but in this study we have not shown any lowering of blood glucose level from short periods of $\overline{0}$. exercise in a study designed to show even small $\overrightarrow{\vec{F}}$ benefits. This is surprising as the exercise was $\stackrel{\mathcal{O}}{+}$ conducted at a time when high circulating insulin levels would be expected. ${ }^{21}$ However, as the intention $\frac{\bar{\sigma}}{\bar{N}}$ of the study was to show the effect of the type of $\frac{\bar{D}}{\sigma}$ exercise that these children normally take, the $\stackrel{\varnothing}{\varrho}$ amount of exercise taken varied considerably. The $\$$ children may have failed to follow the instructions $\overrightarrow{0}$ correctly, although all appeared to have exercised at the correct times.

Our study confirms the frequency of hyperglycaemia after breakfast in diabetic children. Beans virtually abolish the post-prandial hyperglycaemia or without increasing the risk of hypoglycaemia or. requiring the dose of insulin to be altered. Until more $\vec{N}$ acceptable bean recipes are found, diabetic children 8 and their families should be encouraged to avoid of highly refined foods.

We thank Angela Brimble for the blood glucose analyses and Margaret Roberts for secretarial help.

\section{References}

1 Miranda P M, Horwitz D L. High-fiber diets in thg $\overrightarrow{0}$ treatment of diabetes mellitus. Ann Intern Med 1978; 88 482-6.

2 Rivellese, A Riccardi G, Giacco A, et al. Effect of dietaf fibre on glucose control and serum lipoproteins in diabetic patients. Lancet 1980; ii: 447-50.

3 Simpson H C R, Simpson R W, Lousley S, et al. A high carbohydrate leguminous fibre diet improves all aspects $\mathrm{O}$ diabetic control. Lancet 1981 ; i: 1-5.

4 Monnier L H, Blotman M J, Colette C, Monnier M P, Mirouze $\mathbf{J}$. Effects of dietary fibre supplementation in stable and labile insulin-dependent diabetics. Diabetologia 1981 ; 20: 12-7.

5 Kay R M, Grobin W, Track N S. Diets rich in natural fibre improve carbohydrate tolerance in maturity-onset, non-insulin dependent diabetics. Diabetologia 1981; 20: 18-21.

6 The Nutrition Sub-committee of the British Diabetic Association's Medical Advisory Committee. Dietary recommendations for diabetics for the 1980s. London: British Diabetic Association, 1982: 12.

7 Jenkins D J A, Wolever T M S, Taylor R H, Barker H M, Fielden H. Exceptionally low blood glucose response to dried beans: comparison with other carbohydrate foods. Br MedJ 1980; 281 : 578-80.

8 Jenkins D J A, Wolever T M S, Jenkins A L, Taylor R H, Barker $H$ M, Fielden $H$. Effect of guar crispbread with cereal products and leguminous seeds on blood glucose concentrations of diabetics. Br Med J 1980; 281 : 1248-50.

9 Jenkins D J A, Wolever T M S, Taylor R H, et al. Rate of digestion of foods and postprandial glycaemia in normal and diabetic subjects. Br Med J 1980; 281: 14-7.

10 Jenkins D J A, Wolever T M S, Nineham R, et al. Improved glucose tolerance four hours after taking guar with glucose. Diabetologia $1980 ; 19: 21-4$.

11 Kinmonth A L, Angus R M, Jenkins P A, Smith M A, Baum $J$ D. Whole foods and increased dietary fibre , 
improve blood glucose control in diabetic children. Arch Dis Child 1982; 57: 187-94.

12 Wakelin K, Goldie D J, Hartog M, Robinson A P. Measurement of capillary blood glucose in filter-paper spots: an aid to the assessment of diabetic control. $\mathrm{Br} \mathrm{Med}$ J 1978; ii: 468-9.

13 Malone J I, Hellrung J M, Malphus E W, Rosenbloom A L, Grgic A, Weber F T. Good diabetic control-a study in mass delusion. J Pediatr 1976; 88: 943-7.

14 Baumer J H, Edelsten A D, Howlett B C, Owens C, Pennock C A, Savage D C L. Impact of home blood glucose monitoring on childhood diabetes. Arch Dis Child 1982; 57: 195-9.

15 Werther G A, Jenkins P A, Turner R C, Baum J D. Twenty-four-hour metabolic profiles in diabetic children receiving insulin injections once or twice daily. $\mathrm{Br} \mathrm{Med} J$ $1980 ; 281$ : 414-8.

16 Langdon D R, James F D, Sperling M A. Comparison of single and split-dose insulin regimens with twenty-fourhour monitoring. J Pediatr 1981 ; 99: 854-61.
17 Kinmonth A L, Baum J D. Timing of pre-breakfast insulin injection and postprandial metabolic control in diabetic children. $\mathrm{Br}$ Med J 1980; 280: 604-6.

18 Reaven G M. How high the carbohydrate? Diabetologia 1980; 19: 409-13.

19 Mann J I. Diet and diabetes. Diabetologia 1980; 18: 89-95.

20 Bingham S, Cummings J H, McNeil N I. Intakes and sources of dietary fiber in the British population. $\mathrm{Am} \mathrm{J}$ Clin Nutr 1979; 32: 1313-9.

21 Vranic M, Berger M. Exercise and diabetes mellitus. Diabetes 1979; 28 : 147-63.

Correspondence to $\mathrm{Dr} \mathbf{J} \mathbf{H}$ Baumer, Department of Paediatrics, Plymouth General Hospital, Longfield House, Longfield Place, Plymouth PL4 7LY, Devon.

Received 21 June 1982 